\title{
Review on the titanium oxide for catalytic applications
}

\author{
Ecaterina Magdalena MODAN* \\ University of Pitesti, Pitesti, Romania \\ ${ }^{*}$ Corresponding author e-mail: magdamodan@yahoo.com \\ Article history \\ Received 20.06.2019 \\ Accepted 15.08.2019 \\ DOI https://doi.org/10.26825/bup.ar.2019.007
}

\begin{abstract}
Titanium dioxide $\left(\mathrm{TiO}_{2}\right)$ presents particular importance, due to its general properties in a wide range of fields, such as catalysis, photocatalysis and antibacterial agents and as nano-paint (self-cleaning). Physical and chemical characteristics of $\mathrm{TiO}_{2}$, particle size and shape, phases of crystalline $\mathrm{TiO}_{2}$ with band gaps that rutile $\mathrm{TiO}_{2}$ of $3.0 \mathrm{eV}$ and anatase $\mathrm{TiO}_{2}$ of $3.2 \mathrm{eV}$, determine the photocatalytic performance of $\mathrm{TiO}_{2}$. This review presents the theoretical concepts of the structure properties of this oxide and the elaboration methods that make $\mathrm{TiO}_{2}$ the ideal candidate for catalytic applications.
\end{abstract}

Keywords: titanium oxide,rutil, anatase, properties, morphologies, elaboration

\section{Introduction}

Titanium oxide $\left(\mathrm{TiO}_{2}\right)$ is one of the most studied inorganic compounds in chemistry; because it is an alkaline oxide whose synthesis, physical and chemical properties, and uses have been the subject of numerous studies, for all its crystallographic forms (anatase - A, rutile - R and brookite - B).

Titanium oxide $\mathrm{TiO}_{2}$ is a material of great interest due to the chemical, physical, optical and electronic properties that make this material a reference in several catalytic applications. Its properties depend on the crystal, structure, size of the particle that influences the surface.

A large number of applications, such as air and water treatment, self-cleaning surfaces, electronic devices and solar cells, have been reported in the literature [1-8]. Recently, Fujishima and his colleagues have highlighted the large number of publications on this metal oxide with catalytic applications [9]. Numerous articles address on the topic of $\mathrm{TiO}_{2}$ perspectives from the point of view of: heterogeneous photochemistry, photochemistry interspersed with the chemistry, physics and engineering of this material. There are also reviews that address the role of $\mathrm{TiO}_{2}$-based materials in areas such as photo catalytic splitting of water and obtaining hydrogen, photo electrochemistry, dye sensitization and conversion of solar energy, designing reactors and kinetic processes, as well as photochemical treatments of air and water [10-12].

\section{Structure and properties}

Titanium oxide occurs naturally in three crystalline structures: rutile, anatase and brookites. All three structures are composed of a $\mathrm{TiO}_{6}$ octahedron linked in different ways.

The $\mathrm{TiO}_{2}$ structure consists of $\mathrm{TiO}_{6}$ octahedral chains, where each $\mathrm{Ti}$ atom is surrounded by 6 oxygen 
atoms. The unit cell of the tetragonal anatase contains four units $\mathrm{TiO}_{2}$ (12 atoms), while the unit cell of the tetragonal rutile contains two units $\mathrm{TiO}_{2}$ (6 atoms), and the unit cell of the orthorombic brook contains eight units $\mathrm{TiO}_{2}$ (24 atoms).

Thus, anatase has a smaller cell volume than that of rutile and brookite. Therefore, most scientific work was done with anatase or rutile. Brookit is the least stable phase of the three structures, due to the orthorhombic structure, so it is difficult to elaborate [13]. Figure 1. and 2 show the $\mathrm{TiO}_{6}$ structure and the crystalline $\mathrm{TiO}_{2}$ structures: rutile, anatase and brookites.

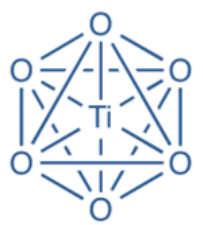

a) $\mathrm{TiO}_{6}$ structure

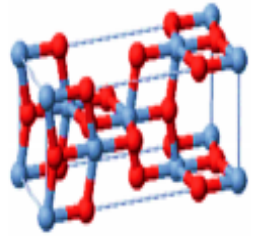

b) Anatas

Figure 1.

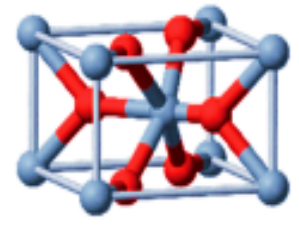

c) Rutile

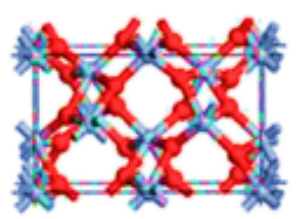

d) Brookit

(tetragonal structure) (simple tetragonal structure) (orthorhombic) $[13,14]$

Each structure has different physical properties. Of these, rutile is the most stable phase under environmental conditions, while anatase and brookite are metastable and will become rutile when heated. Some studies have reported that the stability of the different $\mathrm{TiO}_{2}$ phases depends on the particle size. Anatase is the most thermodynamically stable phase when nanoparticles are smaller than $11 \mathrm{~nm}$, and rutile has been shown to be the most stable for nanoparticles larger than $35 \mathrm{~nm}$ [14]. The anatase phase of $\mathrm{TiO}_{2}$ is known for its applications in photo catalysis, gas sensor, solar cells and electrochemical systems. The rutile phase of $\mathrm{TiO}_{2}$ (simple tetragonal) has applications in the construction of electric capacitors, filters, power circuits and capacitors due to its high dielectric constant [15]. $\mathrm{TiO}_{2}$ has been extensively studied in various photo catalytic systems, including photodegradation of volatile organic compounds, hydrogen production and other environmental applications due to its n-type semiconductor properties, with a range of 3.0 to $3.2 \mathrm{eV}$ (depending on crystallographic variants), low toxicity potential, good chemical and thermal stability, surface acidity and selectivity [16-19]. The properties and applications of titanium oxide are summarized in Table 1.

Table 1. Examples of properties and applications of titanium oxide

\begin{tabular}{|c|l|l|l|}
\hline $\mathrm{TiO}_{2}$-phase & \multicolumn{1}{|c|}{ Color } & \multicolumn{1}{|c|}{ Properties } & \multicolumn{1}{c|}{ Applications } \\
\hline $\begin{array}{c}\text { Anatase - } \\
\mathrm{TiO}_{2}\end{array}$ & $\begin{array}{l}\text { Brown to } \\
\text { black }\end{array}$ & $\begin{array}{l}\text { Polymorphic, metastable, lower } \\
\text { absorption rate, high density, higher } \\
\text { gap }\end{array}$ & $\begin{array}{l}\text { Paints, papers, ceramics, solar cells, } \\
\text { photocatalysis, etc }\end{array}$ \\
\hline Rutil - $\mathrm{TiO}_{2}$ & Dark red & $\begin{array}{l}\text { High refractive index, hard, } \\
\text { chemically resistant, UV absorbent, } \\
\text { obtained at high temperature }\end{array}$ & $\begin{array}{l}\text { Paints, paper, plastic, food, sunscreen, } \\
\text { photocatalysis, interference } \\
\text { applications }\end{array}$ \\
\hline $\begin{array}{c}\text { Brookite - } \\
\mathrm{TiO}_{2}\end{array}$ & $\begin{array}{l}\text { Dark brown to } \\
\text { blackish green }\end{array}$ & $\begin{array}{l}\text { Fragile, very rarely metastable } \\
\text { polymorph, non-fluorescent }\end{array}$ & $\begin{array}{l}\text { Photocatalysis, photovoltaic devices, } \\
\text { jewelry }\end{array}$ \\
\hline
\end{tabular}

The structure dimension of $\mathrm{TiO}_{2}$ has an impact on its properties and on the photocatalytic activity [2021].In Figure 2, types of titanium oxide morphologies are presented based on its size.

Different methods of titanium dioxide elaboration, including hydrothermal methods and sol-gel processes using a variety of precursors such as titanium alkoxides, titanium tetrachloride have been reported by Kobayashi and co-workers 2007, Adjimi and co-workers 2014, Elsellami and its collaborators 2017 [25-27]. 

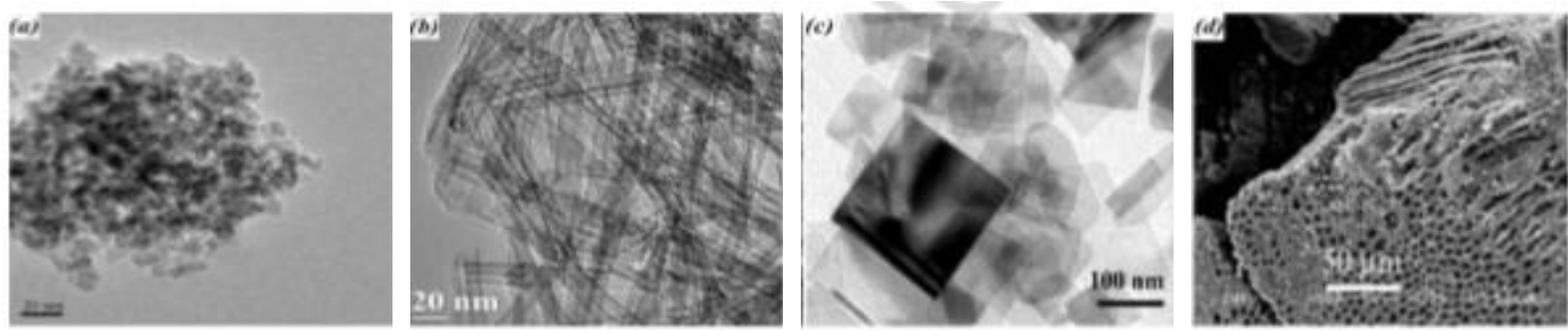

Figure 2. Examples of $\mathrm{TiO}_{2}$ morphologies based on their size a) 0D- Nanoparticles [22], b) 1DNanotubes Nanofibers [23], c) 2D- Nanoplates [23] and d) 3D- Porous structures [24]

\section{Methods of elaboration}

\subsection{Hydrothermal method}

Hydrothermal method is an important method for elaboration mono-dispersed and homogeneous nanoparticles. By this method, nanoparticles, nanotubes, nanofibers, nanowires, nanoparticles and porous structures of titanium oxide were obtained from various precursors. The researchers in the field studied in detail the hydrothermal synthesis of $\mathrm{TiO}_{2}$ particles, the influence of various parameters, such as temperature, experimental duration, pressure, solvent type and $\mathrm{pH}$. The synthesis of $\mathrm{TiO}_{2}$ is usually performed in small Morey type autoclaves fitted with teflon coatings. Depending on the solvent used, the synthesis procedure can generally be classified in two methods:

- the acid hydrothermal method consists of the use of the reactants: titanium salts and concentrated hydrochloric acid $(\mathrm{HCl})$;

- alkaline hydrothermal method consists of the use of reagents: titanium salts and concentrated sodium hydroxide $(\mathrm{NaOH})$.

These two methods have a different reaction mechanism, which produce different morphological characteristics of $\mathrm{TiO}_{2}$.

Additional hydrothermal conditions such as precursor type, $\mathrm{NaOH}$ solvent concentration, temperature and reaction time can affect the structure and morphology of the nanostructures.

In the study by Chen and his colleagues, they developed titanium oxide (anatase, rutile and brookite) using as a precursor titanium butoxide by hydrothermal treatment in concentrated aqueous $\mathrm{HNO}_{3}$ solution at $180^{\circ} \mathrm{C}$ for 24 hours. X-ray diffraction (XRD) results indicated that, as the acidity of the reaction medium was decreased, the content of anatase and rutile increased and decreased, while brookite formation was not affected. At the same time, the degree of crystallinity, crystal size and pore size decreased and the specific surface area was improved [31].

Similar relationships between phase content and acidity were also found by other researchers during the hydrothermal treatment of titanium oxide in ethanol-water solution.

Recently, Cano-Casanova and his colleagues conducted a detailed study on the crystalline structure of $\mathrm{TiO}_{2}$ photocatalysts, elaborated by this method using TIP and $\mathrm{HCl}(0.5-12 \mathrm{M})$ titanium isopropoxide precursor. The $\mathrm{HCl}$ concentration had a major impact on the phase and size of the crystal. As the $\mathrm{HCl}$ concentration increased to $3 \mathrm{M}$, the phase content of anatase decreased, while the content of rutile and brookite increased steadily. At higher concentrations of $\mathrm{HCl}$, the percentage of anatase increased with acidity of the solution and the content of rutile and brookite naturally decreased [32].Yu and his colleagues evaluated the rate of formaldehyde degradation under visible light over reduced graphene oxide (rGO) with $\mathrm{TiO}_{2}$, elaborated by the hydrothermal reaction between TBOT and graphite powder [33]. Table 2 summarizes the morphologies of titanium oxide, the precursors used, the method of elaboration and characterization.

Tabel 2. Morphologies of titanium oxide, precursors, reaction parameters in the hydrothermal method

\begin{tabular}{|c|c|c|c|c|c|c|c|c|}
\hline Precursors & Hydrolysis agent & $\begin{array}{c}\text { Parameters } \\
\mathrm{T}\left({ }^{\circ} \mathrm{C}\right) \\
\mathrm{t}(\mathrm{h})\end{array}$ & Morphology & $\begin{array}{l}\text { Character } \\
\text { ization } \\
\text { method }\end{array}$ & $\begin{array}{l}\text { Crystal } \\
\text { Phase }\end{array}$ & $\begin{array}{c}\text { BET } \\
\left(\mathrm{m}^{2} / \mathrm{g}\right)\end{array}$ & $\begin{array}{l}\text { Dim. } \\
\text { crystal }\end{array}$ & $\begin{array}{l}\text { Ref. } \\
\text { bibl. }\end{array}$ \\
\hline $\begin{array}{l}\text { Titanium } \\
\text { butoxide }\end{array}$ & $\begin{array}{l}\mathrm{NaOH} \\
\mathrm{HNO}_{3}\end{array}$ & $\begin{array}{c}180^{\circ} \mathrm{C} \\
24 \mathrm{~h}\end{array}$ & & XRD & $A+R+B$ & 92-137 & $7.5-23$ & [31] \\
\hline Titanium & $\mathrm{EtOH}, \mathrm{H}_{2} \mathrm{O}$ & $180^{\circ} \mathrm{C}$ & & XRD, & $\mathrm{A}+\mathrm{B}$, & $100-$ & $8-24$ & [32] \\
\hline
\end{tabular}




\begin{tabular}{|c|c|c|c|c|c|c|c|c|}
\hline Precursors & Hydrolysis agent & $\begin{array}{c}\text { Parameters } \\
\mathrm{T}\left({ }^{\circ} \mathrm{C}\right) \\
\mathrm{t}(\mathrm{h})\end{array}$ & Morphology & $\begin{array}{c}\text { Character } \\
\text { ization } \\
\text { method }\end{array}$ & $\begin{array}{l}\text { Crystal } \\
\text { Phase }\end{array}$ & $\begin{array}{c}\text { BET } \\
\left(\mathrm{m}^{2} / \mathrm{g}\right)\end{array}$ & $\begin{array}{l}\text { Dim. } \\
\text { crystal }\end{array}$ & $\begin{array}{l}\text { Ref. } \\
\text { bibl. }\end{array}$ \\
\hline isopropoxide & $\mathrm{HCl}$ & $12 \mathrm{~h}$ & \multirow{2}{*}{$\begin{array}{c}\text { nanoparticles } \\
\text { spherical }\end{array}$} & SEM, & $A+B+R$ & 135 & & \\
\hline $\begin{array}{l}\text { Titanium } \\
\text { butoxide }\end{array}$ & $\begin{array}{c}\text { Graphite powder; } \\
\mathrm{H}_{2} \mathrm{SO}_{4} ; \mathrm{KMnO}_{4} ; \\
\mathrm{H}_{2} \mathrm{O}_{2} ; \mathrm{HCl} \\
\mathrm{NaNO}_{3}\end{array}$ & $\begin{array}{c}180^{\circ} \mathrm{C} \\
12 \mathrm{~h}\end{array}$ & & $\begin{array}{c}\text { XRD, } \\
\text { TEM, } \\
\text { XPS, } \\
\text { Raman } \\
\text { spectrosc } \\
\text { opy; UV- } \\
\text { vis }\end{array}$ & $\mathrm{A}$ & $\begin{array}{c}62,5- \\
100\end{array}$ & - & [33] \\
\hline
\end{tabular}

\subsection{SOL-GEL Method}

Sol-gel is represented by the process of hydrolysis of the alkoxides is the most used method of elaboration of $\mathrm{TiO}_{2}$ with photocatalytic properties, since the equipments and precursors necessary for the elaboration of the method are cheap. $\mathrm{TiO}_{2}$ nanopowders can be obtained by hydrolysis of titanium alkoxides. The process parameters influence the properties of the resulting products. Of these I mention:

- concentration of reactants;

- $\mathrm{pH}$ of the solution;

- the temperature at which the hydrolysis process takes place;

- the nature of catalysts.

The general reaction equation of the process is:

$$
\mathrm{Ti}(\mathrm{OR}) \mathrm{n}+\mathrm{H}_{2} \mathrm{O} \rightarrow \mathrm{TiO}_{2}+\mathrm{R}-\mathrm{OH}
$$

If titanium tert-isopropoxide is used, the chemical reaction is as follows:

$$
\mathrm{Ti}\left(\mathrm{CH}_{3}-\mathrm{CH}_{2}-\mathrm{CH}_{2}-\mathrm{OH}\right)_{4}+2 \mathrm{H}_{2} \mathrm{O} \rightarrow \mathrm{TiO}_{2}+4 \mathrm{CH}_{3}-\mathrm{CH}_{2}-\mathrm{CH}_{2}-\mathrm{OH}
$$

In the case of titanium butoxide, the chemical reaction is as follows:

$$
\mathrm{Ti}\left(\mathrm{CH}_{3}-\mathrm{CH}_{2}-\mathrm{CH}_{2}-\mathrm{CH}_{2}-\mathrm{OH}\right)_{4}+2 \mathrm{H}_{2} \mathrm{O} \rightarrow \mathrm{TiO}_{2}+4 \mathrm{CH}_{3}-\mathrm{CH}_{2}-\mathrm{CH}_{2}-\mathrm{CH}_{2}-\mathrm{OH}
$$

O. Kaygili et all. used titanium tetra-isopropoxide precursor in ethyl alcohol to which $100 \mathrm{ml}$ of distilled water was added. The obtained solution was stirred continuously for 10 minutes to obtain the gel. Thereafter, it was stirred without heating for $2 \mathrm{~h} 30 \mathrm{~min}$ in a magnetic stirrer. This was introduced into an oven, maintained at $60^{\circ} \mathrm{C}$ for 24 hours and further dried at $800 \mathrm{C}$ for 22 hours. Omer calcined the gel obtained at $11000 \mathrm{C}$ for $2 \mathrm{~h}$ to form white $\mathrm{TiO}_{2}$ powder [34]. BK. Mutuma et all used titanium tetra-isopropoxide as precursor to which $30 \mathrm{ml}$ of isopropyl alcohol was added and stirred for $20 \mathrm{~min}$. Deionized water $(300 \mathrm{ml})$ was added to the mixture under vigorous stirring. The solution was heated to $80^{\circ} \mathrm{C}$ for 5 hours and then cooled to room temperature. After cooling, the $\mathrm{pH}$ of the solution was controlled by the addition of $1 \mathrm{M} \mathrm{NaOH}$ or $1 \mathrm{M} \mathrm{HNO}_{3}$ to obtain soils at $\mathrm{pH} 2,4,7$ and 9 . The soils were allowed to gel at room temperature $\left(25^{\circ} \mathrm{C}\right)$ for 24 hours. h. The obtained gels were filtered, washed with distilled water and then rinsed with ethanol and dried at $100^{\circ} \mathrm{C}$ for $12 \mathrm{~h}$. The samples were calcinated at $200^{\circ} \mathrm{C}, 600^{\circ} \mathrm{C}$ and $800^{\circ} \mathrm{C}$ for $2 \mathrm{~h}$. In this work BK. Mutuma highlights the formation of $\mathrm{TiO} 2$ nanoparticles with anatase - brookite using pH control [35]. Unlike O. Kaygili and BK. Mutuma, N.Varghese et all. used tetra-isopropoxide precursor titanium, 2-propanol and deionized water in molar ratio of 1: 2: 12. After stirring the solution, gelatin and nitric acid were added. The SEM and XRD results demonstrate that the use of gelatin in the sol-gel method of titanium oxide nanoparticles rutile phase, improves crystallinity and decreases the particle size, so with and without gelatin, the particle size was $40 \mathrm{~nm}$ and $20 \mathrm{~nm}$ respectively [36]. By this method $\mathrm{TiO}_{2}$ films can be obtained on different substrates.

Thus, M. Vishwas and his colleagues and T. Rattana and collaborators obtained $\mathrm{TiO}_{2}$ films on different substrates. For example, M. Vishwas and his colleagues used ITO-coated glass substrate dissolved $10 \mathrm{ml}$ of titanium isopropoxide in $100 \mathrm{ml}$ of ethyl alcohol (99.8\%). After the addition of concentrated $\mathrm{HCl}$, the solution was stirred for up to half an hour. The clear solution was obtained which was kept in a sealed beaker for two hours for gel formation. The solutions were centrifuged on 
the glass substrate to obtain films. Then, the films were preheated to $60^{\circ} \mathrm{C}$ for 6 hours and then annealed at different temperatures $200^{\circ} \mathrm{C}, 250^{\circ} \mathrm{C}$ and $300^{\circ} \mathrm{C}$ for 6 hours [37].

T. Rattana et al. Obtained $\mathrm{TiO}_{2}$ films on silicon plate substrate, stainless steel, and glass sheet. Thus, $100 \mathrm{ml}$ of $0.2 \mathrm{M}$ titanium tetra-isopropoxide was added to isopropanol under continuous stirring. Add small amounts of deionized water to the precursor solution. The solution was stirred for 10 min before nitric acid was added to adjust the $\mathrm{pH}$ to 2 . The precursor solution was further stirred at room temperature for 1 hour until the homogeneous solution was obtained. The precursor solution was coated on a glass blade, stainless steel and silicon plate. The prepared films were dried at $90{ }^{\circ} \mathrm{C}$ in air for 10 minutes to remove an organic solvent from the films. Finally, the dried films were annealed at $550^{\circ} \mathrm{C}$ for $1 \mathrm{~h}$ [38]. Recent literature reveals that the sol-gel method has proven to be an efficient and versatile method for making $\mathrm{TiO}_{2}$ powders and films.

Table 3 shows the morphologies of titanium oxide, precursors, reaction parameters, method of elaboration and characterization.

Table 3. Morphologies of titanium oxide, precursors, reaction parameters in the sol-gel method

\begin{tabular}{|c|c|c|c|c|c|c|c|}
\hline Precursors & $\begin{array}{l}\text { Hydrolysis } \\
\text { agent }\end{array}$ & $\begin{array}{c}\text { Parameters } \\
\mathrm{T}\left({ }^{\circ} \mathrm{C}\right) \\
\mathrm{t}(\mathrm{h}) \\
\end{array}$ & Morphology & $\begin{array}{c}\text { Characterization } \\
\text { method }\end{array}$ & $\begin{array}{l}\text { Crystal } \\
\text { Phase }\end{array}$ & $\begin{array}{l}\mathrm{BET} \\
\mathrm{m}^{2} / \mathrm{g}\end{array}$ & $\begin{array}{c}\text { Dim } \\
\text { crystal }\end{array}$ \\
\hline $\begin{array}{l}\text { Titanium } \\
\text { butoxide } \\
\mathrm{Ti}(\mathrm{OBu})_{4}\end{array}$ & $\begin{array}{l}\mathrm{EtOH} \\
\mathrm{H}_{2} \mathrm{O}\end{array}$ & $\begin{array}{l}60^{\circ} \mathrm{C} \\
24 \mathrm{~h} \\
80^{\circ} \mathrm{C} \\
22 \mathrm{~h}\end{array}$ & \multirow{3}{*}{$\begin{array}{c}\text { nanopowders, } \\
\text { nanoparticles }\end{array}$} & XRD, EDX & $\mathrm{R}$ & $\begin{array}{l}23,21- \\
27,51\end{array}$ & {$[34]$} \\
\hline $\begin{array}{c}\text { Titanium } \\
\text { tetra- } \\
\text { isopropoxide }\end{array}$ & $\begin{array}{c}\text { Isopropyl } \\
\text { alcohol } \\
\mathrm{NaOH} \\
\end{array}$ & $\begin{array}{c}80^{\circ} \mathrm{C} \\
5 \mathrm{~h}\end{array}$ & & XRD, SEM, & $\mathrm{A}+\mathrm{B}$ & - & [35] \\
\hline $\begin{array}{l}\text { titanium tetra- } \\
\text { isopropoxide }\end{array}$ & $\begin{array}{c}\text { Propanol } \\
\mathrm{H}_{2} \mathrm{O}\end{array}$ & $\begin{array}{c}1000^{\circ} \mathrm{C} \\
2 \mathrm{~h}\end{array}$ & & XRD, SEM & $\mathrm{R}$ & $35-40$ & [36] \\
\hline $\begin{array}{c}\text { Titanium } \\
\text { isopropoxide }\end{array}$ & $\begin{array}{c}\text { Ethyl alcohol } \\
\mathrm{HCl}\end{array}$ & $\begin{array}{l}60^{\circ} \mathrm{C} \\
6 \mathrm{~h}\end{array}$ & \multirow[t]{2}{*}{ filme } & XRD, AFM & A & - & [37] \\
\hline $\begin{array}{l}\text { titanium tetra- } \\
\text { isopropoxide }\end{array}$ & $\begin{array}{c}\text { Isopropanol } \\
\mathrm{HNO}_{3}\end{array}$ & $\begin{array}{c}25^{\circ} \mathrm{C} \\
1 \mathrm{~h}\end{array}$ & & $\begin{array}{c}\text { AFM } \\
\text { Raman }\end{array}$ & A & - & [38] \\
\hline
\end{tabular}

\subsection{Precipitation method}

This method is based on the hydrolysis of the precursors with hydrolysis agents that allow homogenization at the molecular level. By this method, $\mathrm{TiO}_{2}$ nanoparticles were developed.

Namin and his colleagues obtained titanium dioxide nanoparticles by precipitating aqueous solution of TiCl4 with ammonium hydroxide as the precipitating agent. The prepared gel was allowed to crystallize for $6 \mathrm{~h}$ above $9^{\circ} \mathrm{C}$, then dried at $100^{\circ} \mathrm{C}$. Powder X-ray diffraction studies indicate the formation of anatase $\mathrm{TiO}_{2}$ phase with an average crystal size of $4.5 \mathrm{~nm}$ [39].

Research conducted by W. Buraso and co-workers mentions obtaining titanium dioxide nanoparticles by a simple precipitation method using titanium isopropoxide (IV) as a precursor. The precursor powder was calcinated in air at temperatures between $400^{\circ} \mathrm{C}$ and $700^{\circ} \mathrm{C}$. The results of the XRD analysis revealed that the size of the crystallite and the crystallinity of the samples increased with increasing calcination temperature. The calcination temperature had a significant influence on the average particle size, as the size increased from 11.3 to $27.4 \mathrm{~nm}$ when the temperature was raised from $400^{\circ} \mathrm{C}$ to $700^{\circ} \mathrm{C}[40]$.

J. Morales and his collaborators obtained $\mathrm{TiO}_{2}$ nanoparticles, an anatase phase with an average crystallite size of around $20 \mathrm{~nm}$, using the co-precipitation method using titanium butoxide as a precursor. It mixed titanium butoxide, ethanol, glacial acetic acid and sulfuric acid to obtain a white precipitate. The preparation of the starting solution was performed under magnetic stirring and heated to $55^{\circ} \mathrm{C}$. The solution was centrifuged at $3500 \mathrm{rpm}$ for $30 \mathrm{~min}$. The powder was dried at $100^{\circ} \mathrm{C}$ for 2 hours and then calcinated at different temperatures $\left(450^{\circ} \mathrm{C}, 550^{\circ} \mathrm{C}, 600^{\circ} \mathrm{C}, 650^{\circ} \mathrm{C}\right)$ and at different times $(6,12$ and $24 \mathrm{~h})$. According to the structural and morphological characterization, powders calcinated at $650{ }^{\circ} \mathrm{C}$ for 6 hours can be selected as the best to be used in gas detection applications, due to the quality of the anatase phase and the particle size [41]. 
Table 4 shows the titanium oxide morphologies obtained from different precipitating precursors and the morpho-structural characterization results.

Table 4. Morphology of titanium oxide, precursors, reaction parameters in the precipitation method

\begin{tabular}{|c|c|c|c|c|c|c|c|}
\hline Precursors & $\begin{array}{c}\text { Hydrolysis } \\
\text { agent }\end{array}$ & $\begin{array}{c}\text { Parameters } \\
\mathrm{T}\left({ }^{\circ} \mathrm{C}\right) \\
\mathrm{t}(\mathrm{h})\end{array}$ & Morphology & $\begin{array}{c}\text { Characterization } \\
\text { method }\end{array}$ & $\begin{array}{l}\text { Crystal } \\
\text { Phase }\end{array}$ & $\begin{array}{c}\text { BET } \\
\left(\mathrm{m}^{2} / \mathrm{g}\right. \\
)\end{array}$ & $\begin{array}{c}\text { Dim } \\
\text { crysta } \\
1\end{array}$ \\
\hline $\mathrm{TiCl}_{4}$ & $\mathrm{NH}_{4} \mathrm{OH}$ & $\begin{array}{l}90^{\circ} \mathrm{C} \\
6 \mathrm{~h} \\
80^{\circ} \mathrm{C} \\
22 \mathrm{~h}\end{array}$ & \multirow{3}{*}{ Nanoparticles } & XRD, & A & 4,5 & [39] \\
\hline $\begin{array}{c}\text { titanium } \\
\text { tetra- } \\
\text { isopropoxide }\end{array}$ & $\mathrm{H}_{2} \mathrm{O}$ & $\begin{array}{c}80^{\circ} \mathrm{C} \\
12 \mathrm{~h}\end{array}$ & & XRD, SEM, & $\begin{array}{l}\text { A } \\
\mathrm{R}\end{array}$ & $\begin{array}{l}10,2 \\
47,3\end{array}$ & [40] \\
\hline $\begin{array}{c}\text { Titanium } \\
\text { butoxide (IV) }\end{array}$ & $\begin{array}{c}\text { ethanol, } \\
\text { glacial } \\
\text { acetic acid } \\
\text { and sulfuric } \\
\text { acid }\end{array}$ & $\begin{array}{c}100^{\circ} \mathrm{C} \\
2 \mathrm{~h}\end{array}$ & & $\begin{array}{c}\text { XRD, } \\
\text { SEM,TEM }\end{array}$ & $\mathrm{A}$ & $18-22$ & [41] \\
\hline
\end{tabular}

\subsection{Sonochemical method}

The sonochemical approach was used in the synthesis of various nanostructured materials including high surface area colloids, alloys, oxides, carbides and transition metals. In recent years, research has focused on the development of $\mathrm{TiO} 2$ nanoparticles. Arami and his collaborators developed $\mathrm{TiO}_{2}$ nanoparticles, the rutile phase with the average size of the $15 \mathrm{~nm}$ crystallite, the diameter of $20 \mathrm{~nm}$ and the surface area of $78.88 \mathrm{~m}^{2} \mathrm{~g}^{-1}$ by the sonochemical method. They observed that aqueous $\mathrm{NaOH}$ broke the Ti-O-Ti bonds in the $\mathrm{TiO}_{6}$ octahedron during the initial reaction and then new octahedra were developed after ultrasonic irradiation thus leading to nanostructured $\mathrm{TiO}_{2}$ [42].

In the research conducted by A. Ibrahim and his collaborators, they successfully developed this method followed by calcination of $\mathrm{TiO}_{2}$ nanopowders, anatse and rutile phase. They used titanium isopropoxide in $20 \mathrm{ml}$ of ethanol and homogenized for 2 hours. The high intensity ultrasound probe $(750 \mathrm{~W} 20 \mathrm{kHz})$ was immersed directly in the mixed solution at room temperature for $30 \mathrm{~min}$. After the sonochemical process, the prepared precipitate was washed with deionized water and dried in the oven for $30 \mathrm{~min}$. The white precipitates were calcined at different temperatures in the range of $400^{\circ} \mathrm{C}$ to $1000^{\circ} \mathrm{C}$ for 5 hours. The average crystallite size of $\mathrm{TiO}_{2}$ powders at different calcination temperatures was in the range $12-96 \mathrm{~nm}$. The increase of the crystallite size was influenced by the high calcination temperature [43].

In contrast to $\mathrm{H}$. Arami and $\mathrm{A}$. Ibrahim, S.Boini and his colleagues developed by sonochemical synthesis of $\mathrm{TiO}_{2}$ nanoparticles with $50-100 \mathrm{~nm}$ dimensions starting from the tetraisopropoxide precursor titanium, ethanol and sodium hydroxide. The sonochemical process was performed at different amplitudes (50-100). The synthesized $\mathrm{TiO} 2$ nanoparticles were characterized by X-ray diffraction (XRD), transmission electron microscopy (TEM). This method not only helped reduce the size of the $\mathrm{TiO}_{2}$ particles, but significantly reduced the crystal size of the nanoparticles [44].

Table 5 presents the morphologies of titanium oxide, precursors, method of elaboration and characterization.

Table 5. Morphologies of titanium oxide, precursors, reaction parameters in the method of

\begin{tabular}{|c|c|c|c|c|c|c|c|}
\hline Precursors & $\begin{array}{c}\text { Hydrolysis } \\
\text { agent }\end{array}$ & $\begin{array}{c}\text { Parameters } \\
\mathrm{T}\left({ }^{\circ} \mathrm{C}\right) \\
\mathrm{t}(\mathrm{h})\end{array}$ & Morphology & $\begin{array}{c}\text { Characteriza- } \\
\text { tion method }\end{array}$ & $\begin{array}{c}\text { Crysta } \\
1 \\
\text { Phase }\end{array}$ & $\begin{array}{c}\text { BET } \\
\left(\mathrm{m}^{2} / \mathrm{g}\right)\end{array}$ & $\begin{array}{c}\text { Dim } \\
\text { crystal }\end{array}$ \\
\hline $\mathrm{TiO}_{2}$ pellets & $\mathrm{NaOH}$ & $\begin{array}{c}40 \mathrm{kHz} \\
350 \mathrm{~W}) 2 \mathrm{~h} \\
64^{\circ} \mathrm{C} \\
24 \mathrm{~h}\end{array}$ & & SEM, XRD & $\mathrm{R}$ & 15 & {$[42]$} \\
& & & & & & \\
\hline
\end{tabular}




\begin{tabular}{|c|c|c|c|c|c|c|c|}
\hline $\begin{array}{c}\text { Tetra- } \\
\text { izopropoxid de } \\
\text { titan }\end{array}$ & $\begin{array}{c}\text { EtOH, } \\
\text { deionized } \\
\text { water }\end{array}$ & $\begin{array}{c}750 \mathrm{~W} \mathrm{20} \\
\mathrm{kHz} \\
30 \mathrm{~min}\end{array}$ & Nanoparticles & XRD & $\mathrm{A}$ & $12-47$ & {$[43]$} \\
\hline $\begin{array}{c}\text { Tetra- } \\
\begin{array}{c}\text { izopropoxid de } \\
\text { titan }\end{array}\end{array}$ & $\begin{array}{c}\mathrm{NaOH}, \\
\mathrm{EtOH}\end{array}$ & $\begin{array}{c}50-100 \\
\text { Amplitude } \\
\mathrm{h}\end{array}$ & & XRD, TEM & $\mathrm{A}$ & 38 & {$[44]$} \\
\cline { 5 - 8 } & & & & & & \\
\hline
\end{tabular}

\subsection{Microwave assisted method}

This is a simple, biodegradable technique that ensures fast heating. This method allows the elaboration of small metal oxide nanoparticles with the desired crystallinity and good dispersibility.The method requires additional stabilizing agents, thus avoiding contamination of nanoparticles with intermediate products, which is extremely important for catalytic processes.

M. Guel et al elaborated with this $\mathrm{TiO}_{2}$ method. He added a solution of $2 \mathrm{ml}$ of titanium (IV) isopropoxide, $30 \mathrm{ml}$ of 2-propanol and $2 \mathrm{ml}$ of acetic acid or $3 \mathrm{M}$ hydrochloric acid in a Teflon vessel of microwave equipment. This equipment was programmed at a power of $400 \mathrm{~W}$ at a temperature of $80^{\circ} \mathrm{C}$. The obtained soil was kept at room temperature for 24 hours. Then, $8 \mathrm{ml}$ of water was added to form a gel which was dried at $100{ }^{\circ} \mathrm{C}$ for 24 hours. The gel was calcinated at $40^{\circ} \mathrm{C}$ for 3 hours. A single phase of anatase was formed after a reaction time of only $15 \mathrm{~min}$, when acetic acid was used as a catalyst. This time period is considerably shorter than that required by the conventional sol-gel method. When hydrochloric acid was used as a catalyst, the three crystalline phases of $\mathrm{TiO}_{2}$ were observed: anatase, rutile and brookite [45].

Ch. Ashok and his colleagues successfully developed $\mathrm{TiO} 2$ nanoparticles using this method, using titanium isopropoxide and $\mathrm{NaOH}$. To the solution of titanium isopropoxide mixed with $50 \mathrm{ml}$ of distilled water under stirring, $0.01 \mathrm{M} \mathrm{NaOH}$ is added until the solution is white. This obtained solution is introduced in the microwave oven, for 5 minutes forming a white precipitate, finally obtained TiO2 particles of dimensions $18-21 \mathrm{~nm}$ following the characterization by X-ray diffraction. The electron microscopy demonstrated the of spherical $\mathrm{TiO} 2$ nanoparticles [46].

In the research conducted by K.F Moura together with his collaborators, they described the method of elaborating $\mathrm{TiO}_{2}$ with anatase structure using $\mathrm{Ti}$ (IV) isopropoxide and ethanol without alkalizing agents. They prepared an ethanol suspension using Ti (IV) isopropoxide and ethanol under continuous stirring. This suspension was heated by microwave radiation at $1200 \mathrm{C}$ at pressures of approximately $200 \mathrm{kPa}$, for reaction times of 1, 5, 15, 30 and $60 \mathrm{~min}$. During the reaction, a white precipitate formed; after completion of the reaction, this precipitate was washed with distilled water at room temperature until complete neutralization. The precipitate was dried at $100^{\circ} \mathrm{C}$ for 5 hours. Morpho-structural changes were observed with increasing synthesis time and evaluated by chemical calculations. Electron microscopy has demonstrated that titanium oxide particles are obtained when a reaction time of up to 30 minutes is used, but a morphology change also occurs when a reaction time of 60 minutes is used when the formation of morphologies has been observed rod type. The anatase phase was obtained only after $1 \mathrm{~min}$ of reaction in addition to a small amount of brookite phase [47].

Table 6 presents the precursors, parameters and morpho-structural characterization

Table. 6 Morphology of titanium oxide, precursors, reaction parameters in microwave assisted method

\begin{tabular}{|c|c|c|c|c|c|c|c|}
\hline Precursors & $\begin{array}{c}\text { Hydrolysis } \\
\text { agent }\end{array}$ & $\begin{array}{c}\text { Parameters } \\
\mathrm{T}\left({ }^{\circ} \mathrm{C}\right) \\
\mathrm{t}(\mathrm{h})\end{array}$ & Morphology & $\begin{array}{l}\text { Characterization } \\
\text { method }\end{array}$ & $\begin{array}{l}\text { Crystal } \\
\text { Phase }\end{array}$ & $\begin{array}{l}\mathrm{BET} \\
\mathrm{m}^{2} / \mathrm{g}\end{array}$ & $\begin{array}{l}\text { Dim } \\
\text { crystal }\end{array}$ \\
\hline TIP & $\begin{array}{c}\text { Propanol } \\
\text { Ac-COOH } \\
\mathrm{HCl}\end{array}$ & $\begin{array}{l}400 \mathrm{~W} \\
80^{\circ} \mathrm{C}\end{array}$ & \multirow{3}{*}{$\begin{array}{c}\text { nanopowders } \\
\text { Spherical, }\end{array}$} & SEM, XRD & $\begin{array}{c}\mathrm{A} \\
\mathrm{A}+\mathrm{R}+\mathrm{B}\end{array}$ & $11-22$ & [45] \\
\hline TIP & $\mathrm{NaOH}$ & $5 \mathrm{~min}$ & & $\begin{array}{c}\text { SEM, XRD, } \\
\text { TEM }\end{array}$ & - & $18-21$ & [46] \\
\hline TIP & EtOH & $\begin{array}{c}120^{\circ} \mathrm{C} \\
200 \mathrm{KPa}\end{array}$ & & XRD, TEM & A & $\begin{array}{l}57- \\
100\end{array}$ & [47] \\
\hline
\end{tabular}




\section{Conclusion}

From the study of the specialized scientific works on the elaboration and characterization of titanium oxide and iron oxide with catalytic applications, important elements regarding: type of synthesis, methods of morpho-structural characterization, and methods of determining properties has been found. Based on the analysis regarding the researches performed on the synthesis and characterization of titanium oxide, the following conclusions were drawn:

- the stability of the different $\mathrm{TiO}_{2}$ phases depends on the particle size, thus the anatase presents the most thermodynamically stable phase when the nanoparticles are smaller than $11 \mathrm{~nm}$, and the rutile has been shown to be the most stable for the nanoparticles larger than $35 \mathrm{~nm}$;

- the anatase phase of $\mathrm{TiO}_{2}$ is known for its applications in photocatalysis, gas sensor, solar cells and electrochemical systems;

- the rutile phase of $\mathrm{TiO}_{2}$ has applications in the construction of electric capacitors, filters, power circuits and capacitors due to its high dielectric constant;

- the structure dimension of $\mathrm{TiO}_{2}$ has an impact on its properties and on the photocatalytic activity;

- so far, methods for the elaboration of titanium dioxide include chemical syntheses: hydrotermal, sol-gel, co-precipitation, sonochemistry, microwave assisted using a variety of precursors such as titanium alkoxides, titanium tetrachloride, titanium butoxide, titanium isopropoxide;

- the crystallite size of the titanium oxide nanoparticles elaborated by the hydrothermal method varies from $7.5 \mathrm{~nm}$ to $24 \mathrm{~nm}$;

- using the microwave assisted method, titanium oxide nanoparticles were developed whose crystallite size varies from $11 \mathrm{~nm}$ to $22 \mathrm{~nm}$;

- the size of titanium oxide nanoparticles elaborated by the sonochemistry method varies from $15 \mathrm{~nm}$ to $38 \mathrm{~nm}$;

- sol gel method obtained titanium oxide nanoparticles whose crystallite size varies from $23 \mathrm{~nm}$ to $40 \mathrm{~nm}$;

- the size of the titanium oxide nanoparticles elaborated by the precipitation method varies from $4.5 \mathrm{~nm}$ to $47.3 \mathrm{~nm}$;

- the characterization methods used for the morpho-structural characterization of titanium oxide are: SEM, XRD, TEM.

\section{References}

[1] Belver C, Bedia J, Rodriguez J., 2015, Zr-doped $\mathrm{TiO}_{2}$ supported on delaminated clay materials for solar photocatalytic treatment of emerging pollutants. J Hazard Mater 322(Pt A):233-242

[2] Weon S, Choi J, Park T, Choi W., 2017, Freestanding doubly openended $\mathrm{TiO}_{2}$ nanotubes for efficient photocatalytic degradation of volatile organic compounds. Appl Catal B Environ 205:386-392.

[3] Pinho L, Rojas M, Mosquera MJ, 2015, Ag- $\mathrm{SiO}_{2}-\mathrm{TiO}_{2}$ nanocomposite coatings with enhanced photoactivity for self-cleaning application on building materials. Appl Catal B Environ 178: 144-154.

[4] Kim HK, Mhamane D, Kim MS, Roh HK, Aravindan V, Madhavi S, Roh KC, Kim KB 2016, $\mathrm{TiO}_{2}$-reduced graphene oxide nanocomposites by microwave-assisted forced hydrolysis as excellent insertion anode for $\mathrm{Li}$-ion battery and capacitor. J Power Sources 327:171-177. https://doi.org/10.1016/j.

[5] Liang C, Wu Z, Li P, Fan J, Zhang Y, S G, 2016, Chemical bath deposited rutile $\mathrm{TiO}_{2}$ compact layer toward efficient planar heterojunction perovskite solar cells. Appl Surf Sci 391:2-9

[6] Hou Y, Yang J, Jiang Q, Li W, Zhou Z, Li X, Zhou S, 2016, Enhancement of photovoltaic performance of perovskite solar cells by modification of the interface between the perovskite and mesoporous $\mathrm{TiO}_{2}$ film. Sol Energy Mater Sol Cells 155:101-107

[7] Shen Z, Wang G, Tian H, Sunarso J, Liu L, Liu J, Liu S, 2016, Bilayer photoanode films of hierarchical carbon-doped brookite-rutile $\mathrm{TiO}_{2}$ composite and anatase $\mathrm{TiO}_{2}$ beads for efficient dye-sensitized solar cells. Electrochim Acta 216:429-437.

[8] Cui Y, He X, Zhu M, Li X, 2017, Preparation of anatase $\mathrm{TiO}_{2}$ microspheres with high exposure (001) facets as the lightscattering layer for improving performance of dye-sensitized solar cells. J Alloys Compd 694:568- 
573.

[9] Fujishima, A., Zhang, X., \& Tryk, D. A.,2008, Surf. Sci. Rep. 63, 515.

[10] Fujishima, A., Rao, T. N., \& Tryk, D. A., 2000, J. Photochem. Photobiol., C 1, 1.

[11] Henderson, M. A. , 2011, Surf. Sci. Rep. 66, 185

[13] Pelaez, M., Nolan, N., Pillai, S. C., Seery, M. K., Falaras, P., Kontos, A. G., Dulop, P. S. M., Hamilton, J.

W. J., Birne, J. A., O’Shea, K., Entezari, M. H., \& Dionysion, D. D., 2012, Appl. Catal., B 125, 331

[13] K. Bourikas, C. Kordulis and A. Lycourghiotis, Chem. Rev., 2014, 114, 9754-9823.

[14] O. Carp, C. L. Huisman and A. Reller, Prog. Solid State Chem., 2004, 32, 33-177

[15] H. Zhang and J. F. Banfield, J. Phys. Chem. B, 2000, 104, 3481-3487.

[16] K. A. Davis, J. Chem. Educ., 1982, 59, 158.

[17] S. Pavasupree, J. Jitputti, S. Ngamsinlapasathian, S. Yoshikawa, Mat. Res. Bull. 43 2008, 149-157.

[18] Fan Z, Meng F, Zhang M, Wu Z, Sun Z, Li A, 2016, Solvothermal synthesis of hierarchical $\mathrm{TiO}_{2}$ nanostructures with tunable morphology and enhanced photocatalytic activity. Appl Surf Sci 360:298-305.

[19] Li H, Shen X, Liu Y, Wang L, Lei J, Zhang J, 2016, Titanate nanowire as a precursor for facile morphology control of $\mathrm{TiO}_{2}$ catalysts with enhanced photocatalytic activity. J Alloys Compd 687:927-936.

[20] Cortéz-Lorenzo A, Escamilla-Perea L, Esquivel-Escalante K, Velázquez-Castillo R, 2017, Modified gelcasting of microwave assisted synthesized sulfur-doped anatase for photocatalytic degradation of organic compounds. Catal Today 282: 159-167.

[21] Sun S, Zhang J, Gao P, Wang Y, Li X, Wu T, Wang Y, Chen Y, Yang P, 2017, Full visible-light absorption of $\mathrm{TiO}_{2}$ nanotubes induced by anionic S2 2- doping and their greatly enhanced photocatalytic hydrogen production abilities. Appl Catal B Environ 206:168-174.

[22] Nakata, K., Fujishima, A., 2012, $\mathrm{TiO}_{2}$ photocatalysis: Design and applications. Journal of Photochemistry and Photobiology C: Photochemistry Reviews 13, 169-189.

[23] Verbruggen, S.W., 2015, $\mathrm{TiO}_{2}$ photocatalysis for the degradation of pollutants in gas phase: From morphological design to plasmonic enhancement. Journal of Photochemistry and Photobiology C: Photochemistry Reviews 24, 64-82.

[24] Wu, Z., Gu, Z., Zhao, W., Wang, H., 2007, Photocatalytic oxidation of gaseous benzene over nanosized $\mathrm{TiO}_{2}$ prepared by solvothermal method. Chinese Science Bulletin 52, 3061-3067. Xiang, Q., Lv, K., Yu, J., 2010. Pivotal role of fluorine in enhanced photocatalytic activity of anatase $\mathrm{TiO}_{2}$ nanosheets with dominant (001) facets for the photocatalytic degradation of acetone in air. Applied Catalysis B: Environmental 96, 557564.

[25] Hernández-Alonso, M.D., García-Rodríguez, S., Suárez, S., Portela, R., Sánchez, B.,

[26] Wang, M., Zhang, F., Zhu, X., Qi, Z., Hong, B., Ding, J., Bao, J., Sun, S., Gao, C., 2015. Drifts Evidence for Facet-Dependent Adsorption of Gaseous Toluene on $\mathrm{TiO}_{2}$ with Relative Photocatalytic Properties. Langmuir 31, 1730-1736.

[27]Yu, J., Wang, G., Cheng, B., Zhou, M., 2007b, Effects of hydrothermal temperature and time on the photocatalytic activity and microstructures of bimodal mesoporous $\mathrm{TiO}_{2}$ powders. Applied Catalysis B: Environmental 69, 171-180.

[28] Kobayashi M, Tomita K, Petrykin V, Yin S, Sato T, Yoshimura M, Kakihana M., 2007, Hydrothermal synthesis of nanosized titania photocatalysts using novel water-soluble titanium complexes. Solid State Phenom 124-126:723-726.

[29] Adjimi S, Sergent N, Roux J et al ,2014, Photocatalytic paper based on sol-gel titania nanoparticles immobilized on porous silica for VOC abatement. Appl Catal B Environ 154-155: 123-133.

[30] Elsellami L, Dappozze F, Fessi N et al 2017, Highly photocatalytic activity of nanocrystalline $\mathrm{TiO}_{2}$ (anatase, rutile) powders prepared from $\mathrm{TiCl}_{4}$ by sol-gel method in aqueous solutions. Process Saf Environ Prot 113:109-121.

[31] Chen, K., Zhu, L., Yang, K., 2015b. Tricrystalline $\mathrm{TiO}_{2}$ with enhanced photocatalytic activity and durability for removing volatile organic compounds from indoor air. Journal of Environmental Sciences 32, 189-195.

[32] Cano-Casanova, L., Amorós-Pérez, A., Ouzzine, M., Lillo-Ródenas, M.A., Román-Martínez, M.C., 2018, One step hydrothermal synthesis of $\mathrm{TiO}_{2}$ with variable $\mathrm{HCl}$ concentration.

[33] Yu, L., Wang, L., Sun, X., Ye, D., 2018. Enhanced photocatalytic activity of $\mathrm{rGO} / \mathrm{TiO}_{2}$ for the decomposition of formaldehyde under visible light irradiation. Journal of Environmental Sciences 73, 138-146.

[34] Omer Kaygili, Niyazi Bulut, Cengiz Tatar, Tankut Ates, Turan İnce, 2017, Sol-Gel Synthesis And Characterization Of $\mathrm{TiO}_{2}$ Powder, International Journal of Innovative Engineering Applications 1, 238-40. 
[35] Mutuma BK, Shao GN, Kim WD, Kim HT, 2015, Sol-gel synthesis of mesoporous anatase-brookite and anatase-brookite-rutile $\mathrm{TiO}_{2}$ nanoparticles and their photocatalytic properties, J Colloid Interface Sci. Mar 15;442:1-7. doi: 10.1016/j.jcis.2014.11.060.

[36] Neethumol Varghese, Manjusha Hariharan, Dr. A. Benny Cherian, 2015, Rutile Titania Nanoparticles: Effect Of Gelatin On The Sol-Gel Synthesis And It Characterization, International Journal of Technical Research and Applications e-ISSN: 2320-8163, Volume 3, Issue 5 PP. 233-237.

[37] M. Vishwas, Sudhir Kumar Sharma, K. Narasimha Rao, S. Mohan, K. V. Arjuna Gowda And R. P. S. Chakradhar, 2010, Sol Gel Synthesis, Characterization And Optical Properties Of Tio2 Thin Films Deposited On Ito/Glass Substrates Modern Physics Letters B, Vol. 24, No. 807-816 c World Scientific Publishing Company.

[38] Tanattha Rattana, Nirun Witit-anun, Sumetha Suwanboon, Surasing Chaiyakun, 2014, Preparation and properties of $\mathrm{TiO}_{2}$ thin films deposited on different substrates by sol-gel method Advanced Materials Research Vol. 979, pp 355-358.

[39] H.E. Namin, H. Hashemipour, M. Ranjbar, 2008, Effect Of Aging And Calcination On Morphology And Properties Of Synthesized Nanocrystalline $\mathrm{TiO}_{2}$, Inter. J. Mod. Phys. B 22, 3210.

[40] Weeraman Buraso, Vichuda Lachom, Porntip Siriya and Paveena Laoku, 2018, Synthesis of $\mathrm{TiO}_{2}$ nanoparticles via a simple precipitation method and photocatalytic performance, Materials Research Express, Volume 5, Number 11.

[41] J. Morales, A. Maldonado, M. de la L. Olvera, 2013, Synthesis and Characterization of Nanoestructured $\mathrm{TiO}_{2}$ Anatase-phase Powders obtained by the Homogeneous Precipitation Method, Computing Science and Automatic Control (CCE) Mexico City, Mexico.

[42] Hamed Arami, Mahyar Mazloumi, Razieh Khalifehzadeh, S.K. Sadrnezhaad, 2007, Sonochemical preparation of $\mathrm{TiO}_{2}$ nanoparticles, Materials Letters 61, 4559-4561.

[43] Ammar Ibrahim, Wanichaya Mekprasart, Wisanu Pecharapa, 2017, Anatase/Rutile $\mathrm{TiO}_{2}$ composite prepared via sonochemical process and their photocatalytic activity, Materials Today: Proceedings 4, 61596165.

[44] Sriharsha Boini, Niveditha Reddy Barrayb, Naga Ruchira Vajapeyajulac, Shireen Aneesha Koppolic, Sumedha Reddy Vundralac, Basheer Abdulla Mdb, 2018, Structural and Morphological Studies of $\mathrm{TiO}_{2}$ Nanorods synthesized by sonochemical route, International Journal of Current Science, Engineering \& Technology.

[45] M.Andrade-Guel L.Díaz-Jiménez D.Cortés-Hernández C.Cabello-Alvarado C.Ávila-Orta P.Bartolo-Pérez P.Gamero-Melo, 2019, Microwave assisted sol-gel synthesis of titanium dioxide using hydrochloric and acetic acid as catalysts, Volume 58, Issue 4, Pages 171-17.

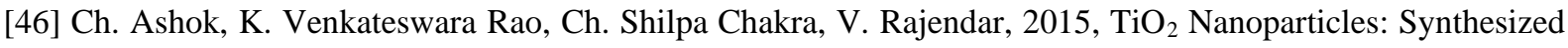
By Simple Microwave - Assisted Method Using Room temperature Ionic Liquids, International Journal Of Multidisciplinary Advanced Research Trends Issn : 2349-7408 Volume Ii, Issue I.

[47] K.F. Moura , J. Maul , A.R. Albuquerque , G.P. Casali, E. Longo , D. Keyson, A.G. Souza , J.R. Sambrano, I.M.G. Santos, 2014, $\mathrm{TiO}_{2}$ synthesized by microwave assisted solvothermal method: Experimental and theoretical evaluation, Journal of Solid State Chemistry 210 171-177. 